\title{
Distinct Substrate Specificity of Cytochrome P450 Dependent Monooxygenase System for Fenvalerate and Diazinon Metabolism in Pyrethroid and Organophosphate Resistant Housefly Strains
}

\author{
Eisuke Funaki,* Walter Curl Dauterman** and Naoki Motoyama \\ Laboratory of Pesticide Toxicology, Faculty of Horticulture, \\ Chiba University, Matsudo, Matsudo 271, Japan
}

(Received July 22, 1993; Accepted March 23, 1994)

\begin{abstract}
The specificity of cytochrome P450 dependent monooxygenases present in housefly microsomes from a susceptible strain, an organophosphate resistant and a Japanese pyrethroid resistant strain was studied using diazinon and fenvalerate as substrates. Both the resistant strains were more active than the susceptible strain in producing $O, O$-diethyl phosphorothioic acid (DEPTA) as well as the sum of diazoxon and $O, O$-diethyl phosphoric acid (DEPA) from ethoxy labeled ${ }^{14} \mathrm{C}$-diazinon. The reaction was not inhibited by the addition of nonradioactive fenvalerate at an equivalent concentration. Utilizing TLC, four radioactive metabolites of phenoxyphenyl-ring labeled ${ }^{14} \mathrm{C}$-fenvalerate were resolved. They corresponded to an unknown metabolite $\mathrm{A}$, a mixture of 4-hydroxy-3-phenoxybenzoicacid (4-HO-PBacid) and ( \pm )- $\alpha$-cyano-4-hydroxy-3-phenoxybenzyl $( \pm)-\alpha$-( $p$-chlorophenyl)isovalerate (4-HO-fenvalerate), 3-phenoxybenzoic acid (PBacid) and fenvalerate. Compared to the susceptible strain, both the resistant strains produced more metabolite A while the pyrethroid resistant strain also produced more PBacid. In contrast, there was little difference in the production of phenoxyphenyl-ring hydroxylated metabolites among the strains. Nonradioactive diazinon inhibited the metabolism of ${ }^{14} \mathrm{C}$-fenvalerate markedly in both the resistant strains, and the inhibition appeared to be of a non-competitive type. CO binding difference spectra revealed a variation in $\lambda_{\max }$ values; 451.5-452 nm for CSMA, 451-451.5 nm for Yachiyo and 450-450.5 $\mathrm{nm}$ for Mashiko strains. These results confirmed the presence in the pyrethroid resistant strain of a cytochrome $\mathrm{P} 450$ species particularly active in the oxidative ester cleavage of fenvalerate. This $\mathrm{P} 450$ species is distinct from the $\mathrm{P} 450$ s responsible for diazinon metabolism or for the metabolism of fenvalerate to metabolite A; the latter P450s being present in both the resistant strains.
\end{abstract}

\section{INTRODUCTION}

The cytochrome P450 dependent monooxygenase system catalyzes the oxidation in phase I reactions of a diverse group of insec-

\section{Present Addresses:}

* Agrochemical Research Department, Ube Research Laboratory, UBE Industries, Ltd., Tokiwadai, Ube 755, Japan.

** Department of Toxicology, North Carolina State University, Box 7633, Raleigh, NC 27695, U.S.A. ticides which include the chlorinated hydrocarbons, or ganophosphates, the carbamates, and the pyrethroids. ${ }^{1)}$ Increased detoxification is one of the more important and ubiquitous factors responsible for insecticide resistance in insects and thus an increase in the cytochrome $\mathrm{P} 450$ dependent monooxygenese system with a broad substrate spectrum is conjectured to be responsible for resistance to various insecticides. Resistance to diazinon in the Rutgers, ${ }^{2,3)}$ the Hokota ${ }^{4}$ and the 
Yachiyo $^{5)}$ strains; to fenitrothion in the Yumenoshima strain, ${ }^{6)}$ and to pyrethroids in the Mashiko strain ${ }^{7)}$ and Learn-Pyr strain $^{8)}$ were attributed at least in part to increased detoxification of these insecticides by the monooxygenase system in these housefly strains. Insect strains with high monooxygenase activity, however, do not necessarily show cross resistance to all the insecticides, indicating the possible existence of cytochrome $\mathrm{P} 450$ species with distinct substrate specificities from each other affording different resistance patterns. The above Yachiyo and Yumenoshima strains, for instance, are extremely resistant to the organophosphates, but show little or no resistance to the pyrethroids. ${ }^{7}$ Another interesting property of the monooxygenase mediated reactions with insecticidal substrates are different multiple sites being attacked on the substrate molecule. Diazinon is thus degraded via pyrimidine ring hydroxylation as well as via desulfuration by the same monooxygenases system. ${ }^{1)}$ Fenvalerate is metabolized mainly via two reactions, oxidative ester cleavage and phenoxyphenyl-ring hydroxylation. ${ }^{9,10)}$ Whether these intra-molecular reactions are catalyzed by the same or different cytochrome $\mathrm{P} 450$ species remains to be clarified using purified enzymes. Since only a few studies are available which purified insect cytochrome P450, though not in a sufficient quantity, comparative studies employing microsomes are imperative to clarify the intra- and inter-molecular specificity of the enzyme. Recently, it is suggested that many different P450 genes may be called upon to provide metabolic resistance in a study using several housefly strains. ${ }^{11)}$ The previous study9) comparing the in vitro and in vivo metabolism of fenvalerate between pyrethroid resistant and susceptible housefly strains suggested the possible involvement of different cytochrome $\mathrm{P} 450$ species in the phenoxyphenyl-ring hydroxylation and in the oxidative ester cleavage.

The purpose of the present investigation was to compare the substrate specificity for diazinon and fenvalerate of cytochrome P450 dependent monooxygenase system using microsomes from organophosphate and a Japanese pyrethroid resistant housefly strains.

\section{MATERIALS AND METHODS}

\section{Chemicals}

A technical grade of $( \pm)-\alpha$-cyano-3-phenoxybenzyl $( \pm)-\alpha-(p$ - chlorphenyl)isovalerate (fenvalerate, $98.0 \%$ ), 4-hydroxy-3-phenoxybenzoic acid (4-HO-PBacid), 3-phenoxybenzoic acid (PBacid), ( \pm )- $\alpha$-cyano-4-hydroxy-3-phenoxybenzyl $( \pm)-\alpha-(p$ - chlorophenyl) isovalerate (4-HO-fenvalerate), and phenoxyphenylring labeled ${ }^{14} \mathrm{C}$-fenvalerate $(99.0 \%)$ with a specific activity of $0.73 \mathrm{MBq} / \mathrm{mg}$ were obtained from Shell Development Co., U.S.A. A technical grade of $O, O$-diethyl $O$-2-isopropyl6 - methylpyrimidin - 4 - yl - phosphorothioate (diazinon, 96.5\%) was obtained from Nihon Kayaku Co., Ltd. Ethoxy $-{ }^{14} \mathrm{C}$ diazinon (spec. act. $0.042 \mathrm{MBq} / \mathrm{mg}$, radiochemical purity $>99 \%$ ) was synthesized and the same compound as described previously. ${ }^{12}$ Reduced form of nicotinamide adenine dinucleotide phosphate $(\beta$-NADPH $)$ was obtained from Oriental Yeast Co., Ltd. Dithiothreitol (DTT), disodium ethylenediamine tetraacetate dihydrate (EDTA), nitrobenzyl-pyridine (NBP), and tetraethylenepentamine were purchased from Wako Chemical Co., Ltd. The other chemicals used in the present paper were of the highest grade commercially available.

\section{Housefly Strains}

The following strains of the housefly, Musca domestica L. were used: CSMA strain from North Carolina State Univ. with $\mathrm{LD}_{50}$ values of $0.03 \mu \mathrm{g} /$ female for diazinon ${ }^{13)}$ and $0.04 \mu \mathrm{g} /$ female for fenvalerate ${ }^{9)}$; Yachiyo strain originally collected from the dumping station of Yachiyo, Chiba-prefecture, Japan in 1984 and selected with diazinon in the laboratory for five generations resulting in $\mathrm{LD}_{50}$ values of 50 $\mu \mathrm{g} /$ female for diazinon ${ }^{5}$ and $0.46 \mu \mathrm{g} /$ female for fenvalerate ${ }^{9)}$; and the Mashiko strain originally collected from a pig farm in Mashiko, Tochigi-prefecture Japan in 1983 and selected with resmethrin in the laboratory for twelve generations resulting in $\mathrm{LD}_{50}$ values of $1.7 \mu \mathrm{g} /$ female for diazinon and $182 \mu \mathrm{g} /$ female for fenvalerate. $^{7)}$ Larvae were reared on $\mathrm{CE}^{\circledR}$ animal feed (Japan Clea Co.) and flies were maintained on a sucrose solution at $25^{\circ} \mathrm{C}$. Female flies, four to six days old, were used in 
the present study, except for the CO-binding spectrum study in which male flies were used.

\section{Enzyme Preparation}

Abdomens were homogenized with $50 \mathrm{~mm}$ phosphate buffer, $\mathrm{pH} 7.6$, containing $10 \%$ glycerol at the rate of 20 abdomens per milliliter using a glass-Teflon homogenizer. Microsomes were prepared from the homogenate by differential centrifugation ${ }^{14)}$ and resuspended in $200 \mathrm{~mm}$ phosphate buffer, $\mathrm{pH} 7.6$, containing $30 \%$ glycerol, $0.25 \mathrm{~m}$ sucrose, $0.1 \mathrm{~mm}$ EDTA, and $0.2 \mu \mathrm{m}$ DTT at the same ratio as the homogenate and were used as the enzyme solution.

\section{Degradation of ${ }^{14} \mathrm{C}$-Labeled Insecticides}

A reaction mixture consisted of $0.5 \mathrm{ml}$ of the microsomal suspension, $0.5 \mu \mathrm{l}$ of $2.2 \mathrm{~mm}$ $\mathrm{NADPH}$ or distilled water, and $10 \mu \mathrm{l}$ of ${ }^{14} \mathrm{C}$ labeled insecticide in acetone. Substrate concentration in the reaction mixture was 1.6 to $15.0 \mathrm{~mm}$ for fenvalerate and $22 \mathrm{~mm}$ for diazinon. In mixed substrate studies, $5 \mathrm{~mm}$ nonradioactive diazinon was added to the reaction mixture containing ${ }^{14} \mathrm{C}$-fenvalerate as the substrate, or $20 \mathrm{~mm}$ nonradioactive fenvalerate was added to the reaction mixture containing ${ }^{14} \mathrm{C}$-diazinon as the substrate. After incubation at $37^{\circ} \mathrm{C}$ for $1 \mathrm{hr}, 1 \mathrm{ml}$ methanol was added to stop the reaction. One hundred microliters of the methanolic solution was applied to precoated silica gel plates (Polygram Sil G/UV254, $0.25 \mathrm{~mm}$ thick, MachereyNagel) and developed twice with the solvent system $n$-hexane: toluene: acetic acid, $3: 15: 2$ $(\mathrm{v} / \mathrm{v} / \mathrm{v})$, to a height of $16.5 \mathrm{~cm}$. Authentic compounds were cochromatographed and visualized under UV. Diazinon metabolites were separated in a similar manner except that the plates were developed first in acetonitrile: water, $85: 15(\mathrm{v} / \mathrm{v})$ to a height of $10 \mathrm{~cm}$ and then with benzene: ethyl acetate, 4:1 $(\mathrm{v} / \mathrm{v})$ to a height of $15 \mathrm{~cm} .{ }^{15)}$ Nonradioactive standards of diazinon and diazoxon were visualized under UV at $254 \mathrm{~nm}$. Silica gel was scraped off at $1 \mathrm{~cm}$ intervals and radioactivity was quantitated by liquid scintillation counting (LSC) (Aloka Liquid Scintillation Spectrometer, LSC 650) using a liquid scintillator. Organophosphorus compounds with $\mathrm{P}=\mathrm{S}$ were visualized by paladium chloride- $\mathrm{HCl}$ spray and those with $\mathrm{P}=\mathrm{O}$ were visualized by $2 \% \mathrm{NBP}$ acetone solution and 10\% tetraethylenepentamine acetone solution sprays. ${ }^{16)}$

\section{CO-Binding Difference Spectra}

CO-binding difference spectra of cytochrome P450 were measured according to the method described by Omura \& Sato ${ }^{17}$ using a Shimadzu UV-240 spectrophotometer.

\section{RESULTS AND DISCUSSION}

TLC radiochromatogram of the metabolites of phenoxyphenyl-ring labeled ${ }^{14} \mathrm{C}$-fenvalerate by microsomes in the presence of NADPH, regardless of the strains, showed four radioactive peaks, A-D. Upon cochromatography with authentic standards, peak B $(R f=0.24)$ chromatographed with 4-HO-PBacid as well as with 4 -HO-fenvalerate, peak $\mathrm{C}(R f=0.52)$ with PBacid, peak D $(R f=0.74)$ with fenvalerate, and peak $\mathrm{A}(R f=0)$ was an unknown. The previous study ${ }^{9}$ indicated the metabolites A, mixture of 4-HO-PBacid and 4-HOfenvalerate and PBacid were produced oxidatively by cytochrome $\mathrm{P} 450$ dependent monooxygenase system, except that a part of metabolite PBacid could also be derived by hydrolysis of fenvalerate.

Table 1 shows a comparison of the metatolite formation by microsomes from different strains and the effect of adding $5 \mathrm{~mm}$ diazinon to the reaction mixture. Only a small difference, if any, was found among the strains in the production of metabolite 4-HO-PBacid and 4-HO-fenvalerate, the phenoxyphenyl-ring hydroxylated products. In contrast, a remarkable interstrain difference was observed in the production of metabolites A and PBacid. The organophosphate resistant strain Yachiyo formed a significantly higher amount of unknown metabolite $\mathrm{A}$, than the susceptible strain while the pyrethroid resistant Mashiko strain formed higher amount of metabolite PBacid than CSMA strain as well. A large part of the metabolite is derived by oxidative cleavage of fenvalerate ester as was shown previously by inhibition studies. ${ }^{9)}$ The different ratio's of the metabolites among the strains suggests the presence of at least two different cytochrome $\mathrm{P} 450$ species with dis- 
Table 1 Comparative metabolism of fenvalerate by microsomes from different housefly strains in the presence of NADPH and the effect of diazinon on the reaction.

\begin{tabular}{lcrrrr}
\hline \multirow{2}{*}{$\begin{array}{c}\text { Housefly } \\
\text { strain }\end{array}$} & $\begin{array}{c}\text { Diazinon } \\
\text { added }\end{array}$ & Unknown & $\begin{array}{l}\text { 4-HO-fenvalerate } \\
\text { +4-HO-PBacid }\end{array}$ & PBacid & Fenvalerate \\
\cline { 3 - 6 } & None & $1.6 \pm 0.3$ & $5.7 \pm 0.2$ & $8.7 \pm 0.5$ & $79.7 \pm 0.8$ \\
CSMA & None & $6.1 \pm 0.2$ & $7.3 \pm 0.3$ & $10.3 \pm 0.4$ & $76.0 \pm 0.8$ \\
Yachiyo & $5 \mathrm{~mm}$ & $2.5 \pm 0.3$ & $4.5 \pm 0.2$ & $7.1 \pm 0.4$ & $85.8 \pm 0.9$ \\
& None & $7.5 \pm 0.5$ & $8.3 \pm 1.4$ & $26.5 \pm 1.2$ & $57.9 \pm 1.2$ \\
Mashiko & $5 \mathrm{~mm}$ & $4.1 \pm 0.7$ & $4.9 \pm 0.6$ & $8.3 \pm 1.4$ & $82.8 \pm 2.8$ \\
\hline
\end{tabular}

a) Metabolites separated by TLC using the solvent system described in the text are expressed as mean $(\%) \pm$ S.D. of three replicates.
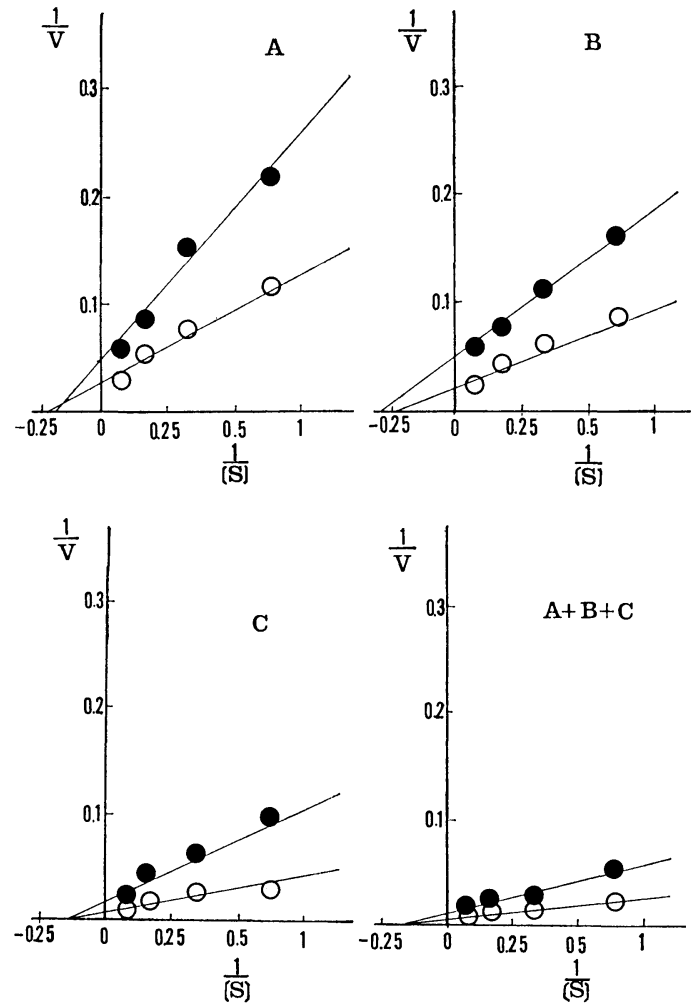

Fig. 1 Lineweaver-Burk plots of the formation of fenvalerate metabolites by microsomes from the Mashiko strain in the presence of NADPH.

The reaction was run in the presence $(\bullet)$ and $a b-$ sence $(O)$ of diazinon. $A=$ unknown, $B=4-\mathrm{HO}$ $\mathrm{PBacid}+4$-HO-fenvalerate, $\mathrm{C}=\mathrm{PBacid}, \mathrm{A}+\mathrm{B}+$ $\mathrm{C}=$ total metabolites.

tinct substrate specificity for fenvalerate metabolism. The addition of diazinon, another nsecticidal substrate, to the reaction medium markedly inhibited the production of all the metabolites in the both resistant strains. Therefore, the effect of the concentration of fenvalerate on its metabolism was investigated in the Mashiko strain in the presence and absence of diazinon. The results are expressed as Lineweaver-Burk plots in Fig. 1. It is obvious from the graphs that the apparent $\mathrm{Km}$ values for each metabolite formed was approximately the same regardless of the presence or absence of diazinon. The noncompetitive type of inhibition of fenvalerate metabolism by diazinon may suggest that cytochrome P450 species (or active sites of the enzyme) responsible for the oxidative metabolism of fenvalerate and of diazinon are probably different.

TLC of the reaction products of ethoxylabeled ${ }^{14} \mathrm{C}$-diazinon by microsomes in the presence of NADPH resolved four radioactive peaks which were identified by cochromatography as $O, O$-diethyl phosphoric acid (DEPA), O,O-diethyl phosphorothioic acid (DEPTA) diazoxon and diazinon. Table 2 shows the percentage of the metabolites formed in different strains and the effect of $20 \mathrm{~mm}$ fenvalerate added to the reaction medium. The largest difference found was in the production of DEPTA, both the Yachiyo and Mashiko strains showing much higher activity than CSMA strain. The Mashiko strain also produced more diazoxon than the CSMA strain, while Yachiyo strain produced more DEPA than the CSMA strain. Since the Yachiyo strain is known to have high phosphorotriesterase activity, ${ }^{5)}$ it is likely that 
Table 2 Comparative metabolism of diazinon by microsomes from different housefly strains in the presence of NADPH and the effect of fenvalerate on the reaction.

\begin{tabular}{|c|c|c|c|c|c|}
\hline \multirow{2}{*}{$\begin{array}{l}\text { Housefly } \\
\text { strain }\end{array}$} & \multirow{2}{*}{$\begin{array}{c}\text { Fenvalerate } \\
\text { added }\end{array}$} & \multicolumn{4}{|c|}{ Percent fenvalerate metabolites $\left.{ }^{a}\right)$} \\
\hline & & DEPA & DEPTA & Diazoxon & Diazinon \\
\hline CSMA & None & $6.2 \pm 0.5$ & $2.7 \pm 0.3$ & $4.5 \pm 0.7$ & $87.1 \pm 1.5$ \\
\hline \multirow[t]{2}{*}{ Yachiyo } & None & $8.9 \pm 0.9$ & $13.8 \pm 0.7$ & $5.5 \pm 0.2$ & $71.8 \pm 1.0$ \\
\hline & $20 \mathrm{~mm}$ & $8.5 \pm 1.0$ & $12.0 \pm 0.7$ & $4.9 \pm 0.3$ & $74.2 \pm 2.2$ \\
\hline \multirow[t]{2}{*}{ Mashiko } & None & $6.4 \pm 0.7$ & $19.1 \pm 0.6$ & $8.7 \pm 1.0$ & $65.0 \pm 1.6$ \\
\hline & $20 \mathrm{~mm}$ & $7.1 \pm 0.7$ & $16.4 \pm 0.2$ & $8.4 \pm 0.2$ & $68.3 \pm 0.7$ \\
\hline
\end{tabular}

a) Metabolites separated by TLC using the solvent system described in the text are expressed as mean $(\%) \pm$ S.D. of three replicates.

DEPA was formed by hydrolysis of diazoxon. Thus, the sum of DEPA and diazoxon may represent the total diazoxon produced. The Mashiko and Yachiyo strains were equally active in this regard and were apparently more active than CSMA strain.

The effect of fenvalerate on diazinon metabolism was minimal, if any, in both the Yachiyo and Mashiko strains, in contrast to the marked effect of diazinon on fenvalerate metabolism. The findings imply that either diazinon is a much better substrate than fenvalerate for the monooxygenase reaction, or the cytochrome P450 species responsible for diazinon metabolism is different from that involved in fenvalerate metabolism. Judging from the interstrain differences found in the present study for the monooxygenase mediated reactions, it seems reasonable to assume that different cytochrome $\mathrm{P} 450$ species are involved in the metabolism of these insecticides.

CO binding spectra obtained with microsomes from different strains are presented in Fig. 2. The $\lambda_{\max }$ values varied slightly depending upon the preparation, although the difference among the strains was consistent. The range of $\lambda_{\max }$ values determined with five microsomal preparations of each strains was $451.5-452 \mathrm{~nm}$ for CSMA, $451-451.5 \mathrm{~nm}$ for Yachiyo, and $450-450.5 \mathrm{~nm}$ for Mashiko strains. The difference in $\lambda_{\max }$ values further supports the presence of different cytochrome P450 species among the three strains.

In conclusion, the microsomes of the Yachiyo and the Mashiko strains appear to contain at least one cytochrome $\mathrm{P} 450$ species which is involved in diazinon metabolism and

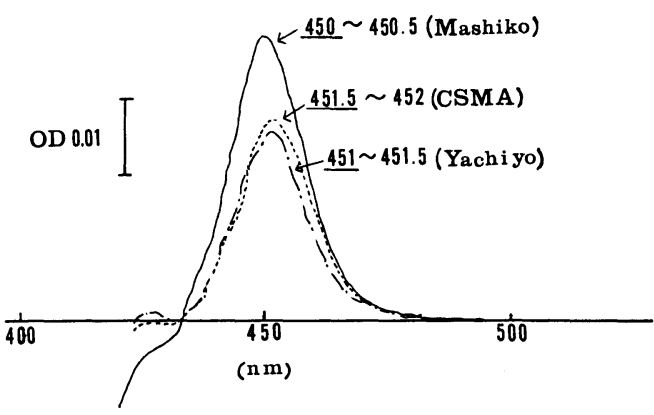

Fig. 2 CO binding difference spectra of cytochrome P450 from susceptible (CSMA), organophosphate resistant (Yachiyo), and pyrethroid resistant (Mashiko) strains of the housefly.

Microsomes equivalent to sixty male abdomens were used for each spectrum. The range of $\lambda_{\max }$ values was determined using six different microsomal preparations of each strain. The underline indicates the value was closer to the number.

is more active than in the CSMA strain in the production of DEPTA and diazoxon. While it is not certain whether this or another cytochrome $\mathrm{P} 450$ species is responsible for the formation of unknown metabolite $\mathrm{A}$ from fenvalerate, microsomes of the Mashiko strain appear to contain an additional cytochrome P450 species which is more active than that in the Yachiyo and CSMA strains for oxidative cleavage of the ester bond of fenvalerate. Scott et al. reported that, although resistant strain has a higher monooxigenase activity than susceptible strain, there is no qualitative difference among $\mathrm{P} 450$ species responsible for insecticide resistance in housefly. ${ }^{18-20}$ ) Feyereisen et al. also reported that many dif- 
ferent P450 genes may be called upon to provide metabolic resistance. ${ }^{11)}$ These results may suggest that a great diversity in $\mathrm{P} 450$ genes correlated with insecticides resistant in housefly.

\section{REFERENCES}

1) A. Y. Kulkarni \& E. Hodgson: Pharmacol. Ther. 8, 379 (1980)

2) R. S. H. Yang, E. Hodgson \& W. C. Dauterman: J. Agric. Food Chem. 19, 14 (1971)

3) D. R. Vincent, A. F. Moldenke, D. E. Farnswort \& L. C. Terriere: Pestic. Biochem. Physiol. 23, 171 (1985)

4) T. Shono: Botyu-Kagaku 39, 75 (1974) (in Japanese)

5) M. Oi, W. C. Dauterman \& N. Motoyama: $J$. Pesticide Sci. 15, 217 (1990)

6) A. Kudamatsu, A. Hayashi \& R. Kano: "Pest Resistance to Pesticides," ed. by G. P. Georghiou \& T. Saito, Plenum Publishing Corporation, New York, pp. 411-419, 1983

7) E. Funaki, Y. Tabaru \& N. Motoyama: J. Pesticide Sci. 11, 415 (1986)

8) J. G. Scott \& G. P. Georghiou: Pestic. Sci. 17, 195 (1986)

9) E. Funaki, W. C. Dauterman \& N. Motoyama: J. Pesticide Sci. 19, 43 (1994)

10) H. Ohkawa, H. Kaneko, H. Tsuji \& J. Miyamoto: J. Pesticide Sci. 4, 143 (1979)

11) R. Feyereisen, F. A. Carino \& J. F. Koener: "Pesticides and the Future," ed. by E. Hodgeson, R. M. Roe \& N. Motoyama, North Carolina State University, Raleigh, North Carolina, pp. 163-171, 1991

12) B. R. Smith, W. C. Dauterman \& E. Hodgson: J. Labelled Compd. 11, 155 (1975)

13) N. Motoyama: J. Pesticide Sci. 9, 523 (1984)

14) L. G. Hansen \& E. Hodgson: Biochem. Pharmacol. 20, 1569 (1971)
15) N. Motoyama \& W. C. Dauterman: Pestic. Biochem. Physiol. 5, 489 (1975)

16) J. M. Follweiler \& J. Sherma: "Handbook of Chromatography," Vol. I, CRC Press, Boca Raton, Florida, pp. 187-289, 1984

17) T. Omura \& R. Sato: J. Biol. Chem. 239, 2370 (1964)

18) J. G. Scott, S. S. Lee \& T. Shono: Pestic. Biochem. Physiol. 36, 127 (1990)

19) S. S. T. Lee \& J.G. Scott: Pestic. Biochem. Physiol. 35, 1 (1989)

20) G. D. Wheelock \& J. G. Scott: Pestic. Biochem. Physiol. 38, 130 (1990)

\section{要 約}

ピレスロイド，有機リン刘抵抗性イエバエにお けるフェンバレレートおよびダイアジノン代謝 に関与するチトクローム $\mathbf{P 4 5 0}$ モノオキシゲ ナーゼ系の基質特異性

船城衛介，Walter C. DAuterman，本山直樹 交差抵抗性パターンの異なるイエバエ系統を用いて， ミクロゾームのレベルで MFO の fenvalerate と diazinon に対する基質特異性を比較した．その結果， fenvalerate の分解は diazinon の添加によって著しく 影響を受けることが明らかになった，しかし， diazinon の分解は fenvalerateによって影響されず，両殺虫剤 基質の分解に関与する $\mathrm{P} 450$ は必ずしも共通ではないこ とを予想させた．また，イエバェ系統間で $\mathrm{CO}$ 差スペ クトルの吸収極大波長に明らかな違いが認められた。こ れらのことより，イエバエのミクロゾームには両殺虫剤 に対する特異性が異なる複数の P450 分子種が含まれ ていることが示唆され，益子系においてはとくに fenvalerate を分解する P450 の活性が高いことが推察さ れた. 